europhysics news extra - EPS information

EurophysNet at http://epswww.epfl.ch/

\section{European Physical Society}

EPS Secretariat, P. O. Box 69,

CH-1213 Petit-Lancy 2, Geneva

Telephone: +41-22-7931130

Telefax: +41-22-7931317

E-mail: eps@cern.ch

WWW: http://epswww.epfl.ch/

EPS counts among its members some 4000 Individual Ordinary Members and 37 National Member Societies throughout Europe whose members participate in EPS activities.

\section{Managing Editor}

P.G. Boswell, EPS Geneva

E-mail: peter.boswell@cern.ch

\section{Subscriptions}

ISSN: 0531-7479

Volume 27: 6 issues will appear in 1996. Recommended annual subscription prices institutions: DM 160.-; individuals DM 98.-Special rate for new individual subscribers: DM $78,-$ for one year. All prices plus carriage. EPS Individual Ordinary Members receive Europhysics News free of charge. Members of EPS National Member Societies except the German Physical Society and the Institute of Physics, UK, receive Europhysics News through their society.

Subscriptions can either be placed via an agent or sent directly to:

Springer-Verlag, Postfach 311340

D-10643 Berlin, Germany

Telephone: $+49-30-8207358$

Telefax: $+49-30-8207448$

E-mail: subscriptions@springer.de Cancellation must be received by September 30 to take effect the following year.

\section{Production}

PRODUserv

Springer Produktionsgesellschaft 3050 Journal Production Department L. Grenzdörfer, Heidelberger Platz 3

D-14197 Berlin, Germany

Telephone: $+49-30-8207750$

Telefax: $+49-30-82$ o7 440

E-mail: grenzdoerfer@springer.de

\footnotetext{
Advertisements

Springer Verlag

E. Lückermann, U. Evert

Springer-Verlag, Postfach 311340

D-14197 Berlin, Germany

Telephone: $+49-30-8207733$

Telefax: $+49-30-8207300$

Advertising is charged according to space and position, pro rata based on DM 3800.- for a full page, black and white. Rates on request. Discounts for EPS Associate Members. Deadline for orders: on request (normally four weeks before publication).
}

\section{Extension}

Readers will have to wait until the next issue for a report of this year's EPS Council which voted to base the Society in Mulhouse as from 1 January 1997. The move is accompanied by a Strategy Plan for EPS and a timetable for implementation that involves a call to the Society's groups and committees for proposals for activities. The bare bones have been distilled down to a list of Council and Executive Committee decisions, drafted as we went to press, which is published in the News from EPS pages.

So the Society's 27-year long Geneva period is coming to an end and with it a mission to bridge east-east west from an open, international city as its base. The new era will maintain the same thrust, but from a different perspective. Coinciding with the Society's decision, Europe's premier body, the European Union, launched an intergovernmental conference that aims to prepare the Union to take in new members from east and central Europe to ensure that democracy and stability take root there. The Union must reform its organization and institutions, invented 40 years ago for a club of six, so that they can function effectively with over 20 member countries. In all due modesty, the discussions at the European level have been mirrored within physics, which has long recognized the need for international cooperation. The conference, as one might expect, will discuss such things as the need for a strengthened supranational body, clubs within the larger club, and an agreed minimum number of activities in which all countries participate.

The discussions will also have to determine if existing mechanisms can take the strain of enlargement. The Union's existing mechanisms for supporting and directing research are embedded in the Framework programme. They are already showing pressure from overdemand (page 65), at least in areas that basic science can identify with relatively easily. Debate on the direction of future Frameworks is based on the European Commission's Green Paper on Innovation that was released last December. It defines innovation as the entire process of bringing scientific ideas to the marketplace an activity in which Europe clearly lags behind on the basis of performance measures such as the amount of high-technology industrial activity, number of patents, etc.

In a position paper on the next Framework, the European Science Foundation will probably stress the importance to innovation in its broadest sense of an openness and two-way interaction between academia and industry. It remains to be seen if this can be achieved by extending and fine-tuning Framework subject to the constraint of subsidiarity whereby the bulk of science funding remains national. D.L. Weaire, the newly elected EPS President-Elect who steps down shortly as the Chairman of an EC panel that evaluates physics networks, believes (page 64) that proposers of networks will be moving in the right direction if they pay more attention to industrial partners.

A recent report by an ad hoc working group on extending the COST mechanism for cooperative research beyond collaboration centred on large facilities argues along the same lines. It says that basic and applied research must now evolve in parallel in areas of technology-driven physics. Once again, the need comes from fierce, world-scale competition in which research follows marketing and production to emerging economies, and the conventional linear model of technological innovation from research to manufacturing breaks down.

P.G. Boswell 